Ref: Tazairt T. et Prim-Allaz I. (2021), Configurational servitization approach: A necessary alignment of service strategies, digital capabilities and customer resources, in Kohtamäki M., Baines T., Rabetino R., Ziaee Bigdeli A., Kowalkowski C., Oliva R. \& Parida V.,The Palgrave Handbook of Servitization: Theories and concepts in servitization and product-service systems, Palgravre McMillan (September).

\title{
Configurational servitization approach: A necessary alignment of service strategies, digital capabilities and customer resources
}

\section{INTRODUCTION: THE COMPLEXITY OF SERVITIZATION}

In order to face down competition and enhance their market share, manufacturing companies need to address their businesses differently, developing either complementary offers or a core transformation of their offer into one that integrates services. These changes can lead to a better response to customer needs, quite often in innovative ways.

Servitization (Vandermerwe \& Rada, 1988) is an evolution of the value proposition of manufacturing firms. It consists of a shift from a product-centric offer to an offer combining products and services, or to a use-centric or a result-centric offer (Baines et al., 2009; Mathieu, 2001).

Servitization is perceived by firms as a way of both improving their competitiveness (Vandermerwe and Rada, 1988) and reaching a higher level of profitability (Gebauer et al., 2011). The service offerings are more likely to provide higher margins and profitability due to their low comparability (Neu \& Brown, 2005; Oliva \& Kallenberg, 2003; Frambach et al., 1998) and to allow manufacturers to be less concerned with price competition (Malleret, 2006).

The research to date highlights that the servitization of manufacturing companies has not always fulfilled its promised performance. Many tensions are observed in the literature, including the 
so-called service paradox (Gebauer, 2005; Neely, 2007). Empirical studies demonstrate that the financial benefits resulting from servitization are not always positive or perceptible (Gebauer, Fleisch \& Friedli, 2005; Neely, 2007). The service development in manufacturing firms should improve their performance, but this is not always the case in practice (Gebauer et al., 2005). This paradox is possibly reinforced by a digitalization paradox, digitalization being considered as a driver as well as an enabler of servitization (Vendrell-Herrero, Bustinza, Parry \& Georgantzis, 2017). The digitalization paradox reflects the fact that the revenues attributable to digitalization are much lower than the costs engaged (Sjödin, Parida, Kohtamäki \& Wincent, 2020). This lack of performance may appear in particular when firms simultaneously develop both their servitization and their digitalization (Vendrell-Herrero et al., 2017).

One way of overcoming these paradoxes is to better understand servitization and its conditions of success. As there is no consensus in the literature on defining servitization, we re-examine the current understanding of servitization and we propose to highlight the heterogeneity of this concept, which is multifaceted and faces different approaches (Table 1): either offer-oriented, processes-oriented, uses or results-oriented or innovation-oriented. These approaches reflect different servitized value propositions (SVP).

The value proposition addresses the relationship between customer needs and supplier offers (Osterwalder et al., 2011), and some scholars put the customer and its resources as a focal point of servitization (Vandermerwe \& Rada, 1988; Ren \& Gregory, 2007; Baines et al., 2009, 2013), showing the importance of the customer in the servitized value proposition. In section 2 , we present and discuss key components of servitization (strategy, value proposition, customer resources and digital capabilities) that companies have to combine. Service strategies and their related servitized value proposition have to be considered through the interplay with the roles given to customers and digitalization in order to perform as expected. 
In section 3, we argue that there are different paths to a successful servitization. Based on configuration theory, we propose an integrative framework to help manufacturing firms to implement servitization according to their chosen strategy. We defend the idea that firms may be perform as expected while implementing different configurations of service strategies, digital capabilities and customer resources (Ambroise et al., 2018).

\section{THEORY DEVELOPMENT}

Understanding the different servitization approaches can help manufacturing companies to better address their servitized value proposition. In the meantime, adopting a value proposition perspective can facilitate a better implementation of servitization. These approaches - offeroriented, processes-oriented, uses or results-oriented and innovation-oriented-are not mutually exclusive and refer to different value propositions (Table 1). 
Table 1. The necessary re-examination of the current understanding of servitization: different servitization approaches 


\subsection{Value propositions and service strategies}

Baines et al., (2019) recommend rethinking servitized value propositions in terms of customers' roles and resources. They define the value proposition (VP) offered to customers as the capacity of firms to combine their offerings (as providers) with the outcomes (the customer benefits inherent to the use of these offerings). In other words, the VP "is presented as a statement that clearly identifies for customers what they will receive and what it will do for them" (p. 4). This definition is completed by "how customers will contribute throw their own proposals (roles and resources)". Indeed, it is important to consider the serivitized value proposition (SVP) of the resources brought by customers in specific transactions and in the whole relationship (Moeller, 2010). Customers may play different roles, with different levels of integration in the value chain.

Baines et al., (2013) suggest a configurative definition of servitization, which integrates the customers in the definition of services, giving specific roles to them and necessitating a different organization according to the types of services. Indeed, the authors propose three types of customised servitization: 1) basic added services for the "do it themselves" category of customers; 2) intermediate services to the "do it with them" customers; and 3) advanced service for the "do it for them" customers. In doing so, the authors fully integrate the customer in their definition of servitization and put the focus on the heterogeneity of customer roles. Many companies emphasize customer roles in their servitized value proposition, showing how to favour a customer-service configuration with shared value creation between customers and suppliers (Neely, 2008). As they move to servitization, manufacturing companies may offer different value propositions to their customers.

We propose three different levels of value propositions for services, inspired by Baines et al. (2019). The first level corresponds to proposing mere added services such as simple product spares, training materials, documentation, breakdown services, consumables and maintenance 
tools (Teyssier et al., 2018; Baines et al., 2019). We name this VP the basic VP. The second level integrates product break/fix, assured maintenance and performance advisory services (Baines et al., 2019) as well as predictive maintenance, monitoring to improve customers' use of equipment, outsourcing, co-design or co-production activities (Teyssier et al., 2018; Gebauer et al., 2010). We name this second type of VP an output-oriented VP. The third level of VP proposes to integrate customers more in the service production in terms of asset, process and platform (Baines et al., 2019) where suppliers (non-transfer of property rights and of associated risks) provide an integrated product-service solution that guarantees different customers' outcomes. We name this VP a customer outcomes-oriented VP.

These VPs are the declination of a variety of strategies. Ambroise et al. (2018) identify three of them: proposing added-services to the core offer; activities reconfiguration; and business model reconfiguration (Table 2 ). 
Table 2. Service strategies and servitized value propositions (Ambroise et al., 2018; Baines et al., 2019) 
In a certain way, these strategies are closed to the typology of customer roles proposed by Baines et al. (2013) — “do it themselves"; "do it with them"; "do it for them"- that takes explicitly into account the resources brought by the customers. Vargo and Lusch (2008) point out the necessity of bringing customers to deliver "applied resources for value creation and collaboratively (interactively) create value" (p. 7). In line with Vargo and Lusch (2003), Baines and Lightfoot (2013) show the key role of customers assuming that the customer is always a co-producer, implying value creation in an interactive manner.

Manufacturing firms increasingly aim to offer a comprehensive commercial proposal by integrating the customers in the offer (Vandermerwe \& Rada, 1988). They put the customer in a central position. The contribution of the customers to the servitized value creation must be considered during the servitized process itself, the customer having more or less active roles in the value proposition design and implementation. Indeed, the customer can contribute to the offer with different levels of resources: a passive customer is considered as a mere consumer; an active one is considered as a producer, and a proactive one is considered as an initiator.

\subsection{Services strategies, digital capabilities and customer resources}

Mobilizing customer resources and considering the customer as a co-producer induces greater information exchange. Servitization globally involves a better knowledge of customer needs and more interactions that are nowadays greatly facilitated by digitalization. Customers and digitalization are both key in elaborating an appropriate value proposition: technologies contribute to improving the value of the offer delivered to customers and the value brought by customers (Ambroise et al., 2018; Coreynen et al., 2017; Tukker, 2004).

Digitalization can help to move to a product-service system (Frank et al., 2019) in which digital capabilities are needed to interact and create value with customers (Lenka et al., 2017). Gobble (2018) considers digitalization as a form of process and business model innovation that enables 
the exploitation of new opportunities to create and capture value (Gobble, 2018) by enhancing customers' analytics and insights, operational efficiency and marketing learning (Ramaswamy \& Ozcan, 2018). We note here the necessary link between digital processes and customers.

Developing a service offering also requires us to reconsider interactions and interfaces with customers (Ambroise et al., 2018) and promotes the development of digital capabilities in companies (Lusch \& Gotsch, 2015; Parida et al., 2015a) to improve customer relations. Nevertheless, the customer interface required differs depending on the service strategy implemented (Ambroise et al., 2018). This interface defines the potential of firms to collect data and automatize part of the relationship.

As mentioned above, these strategies, AS, AR, and BMR, need to address different digital capabilities relating to the customer interface required: informative, collaborative and productive (Teyssier et al., 2018). The first category of capabilities (informative) makes it possible to capture and store information about customers and the environment that the front office receives and generates. The second type of capabilities (collaborative) enables both information exchanges between customers and the back office and co-creating activities; and the third (productive) improves internal operational processes, including design and manufacturing processes, flow and supply chain management (Teyssier et al., 2018).

Companies must take into account their digital capabilities and cutomers' resources in their servitized value proposition. This is especially true in B2B activities in which suppliers are looking for a better understanding of the value creation process (Coreynen, 2017) in order to improve their value proposition and thus move their business to more customer-integrated models (Grandval \& Ronteau, 2011). Informative capabilities are particularly important when developing added services; while collaborative capabilities are important when proposing activities reconfigurations. Productive capabilities are key to business model reconfiguration strategy (Teyssier et al., 2018). 
To conclude, we define the servitized value proposition as an iterative process that allows: i) the identification of customer needs; and ii) the formulation of an optimal response by suppliers through service development and integrated digital capabilities to enable an innovative and configurative model of servitization. The servitized value proposition has to be considered through interaction with the roles given to customers and digitalization in order to perform as expected (Martín-Peña et al., 2019).

Companies that integrate new services by simultaneously developing digitalization processes may face a digital service paradox (DSP) due to the difficulty in finding the right articulation and structure between servitization and digitalization. We define the DSP as a risk of failure in the financial performance of manufacturing companiesthat are trying to enhance their offerings towards more services while enhancing their digital capabilities to meet customers' needs at the same time. In order to overcome this DSP, we argue for the necessity of articulating between: i) customer resources by showing the importance of the customer (and the need to consider it as a resource with varying degrees of integration in the chosen servitized value proposition); and ii) digitalization capabilities to develop new services, and for their integration in the servitized value proposition design. As there is a multiplicity of possible combinations of servitization strategies, customer resources and digitization capabilities, one must consider that different configurations may lead to better performance.

In the next section, we present an integrative framework combining service strategies, digital capabilities and customer resources to design and implement efficient servitized value propositions (Table 2). 


\section{TOWARDS A CONFIGURATIONAL ORIENTATION OF SERVITIZATION}

Ambroise et al. (2018) demonstrate that there is no one best way to implement a service strategy and that customer roles and interfaces have to be adapted to the chosen strategy. As a consequence, we advocate the need for a configurational approach that recognizes the alignment of service strategies, digital capabilities and customer resources to be a necessity.

As service strategies are multiple and potentially very heterogeneous, there is a risk of mismatch between the servitization strategy that is implemented, digital capabilities and customer ressources. This can result in a financial failure and a potential deservitization (Kowalkowski et al., 2017a). Therefore, firms have to be aware of the need to choose relevant configurations (Bowen et al., 1989).

We previously pointed out the complexity and heterogeneity of servitization, both of which often lead manufacturing firms to misunderstand the concept. To design their servitized value proposition, manufacturing firms must have a comprehensive framework of servitization that takes into account service strategies, customer roles and resources and firms' digital capabilities. Previous work has shown that a plethora of different service strategies on offer means that there is no one best way to servitize. A configurational approach is proposed in order to take into account this heterogeneity. Implementing a servitization strategy is not a "straight road to success" (Gebauer et al., 2010b: p. 198).

\subsection{Dimensions of the configurational approach and need for an alignment of service strategy, customer roles and resources and digital capabilities}

In developing the research area of servitization, scholars would be wel advised to identify the conditions for successful implementation of servitization in manufacturing companies. Our essay offers a valuable contribution to the field by providing a perspective that understands the 
configurations of servitized value propositions and considers their strategies and underlying structures as well as their resource contingencies.

Instead of looking for a single condition to determine outcomes, our configuration theory allows for different conditions of successful outcome, considering there is no one best way to achieve performance but a set of combinations (Böhm et al., 2017; Meyer et al., 1993).

The configuration logic is that different interactions between the three domains (strategy, structure, resources) may bring about successful servitization (Kohtamäki et al., 2019). Scholars assume that superior performance can be reached with different pathways: companies should not have a single and common reading of their performance. They have to deal with their own organizational and strategic characteristics (Böhm et al., 2017).

Moreover, the configurational approach advocates non-linearity and equifinality (Meyer et al., 1993; Ragin, 2008) which means that the key attributes are multidimensional, possibly interrelated and have potentially a mutual amplificatory effect. Indeed, researchers have shown that firms with more coherent characteristics outperform firms with less coherent characteristics (Meyer et al., 1993; Vorhies \& Morgan, 2003). Multiple configurations lead to superior performance as long as their individual conditions are aligned (Böhm et al., 2017; Doty, Glick \& Huber, 1993).

Drawing on the research literature to date, we propose that companies adopt a relevant alignment of service strategy, digital capabilities and customer resources. The service strategies typology proposed by Ambroise et al. (2018), added services (AS), activities reconfiguration (AR) and business model reconfiguration strategies (BMR), is complementary to the one proposed by Baines and Lightfoot (2013) ("do it themselves-do it with them- do it for them"). Crossing the two typologies makes it possible to better understand the role customers are expected to perform according to the specific strategy implemented. 
Table 3, below, presents the different attributes for designing and realizing the chosen service strategy based on a configurational approach. When implementing an AS strategy, manufacturing companies are positioned in an offer-oriented and/or a processes-oriented approach to servitization, which implies greater digital informative capabilities.

To address an AR strategy, companies can design either/both a result, processes or usesoriented servitization approach where digital collaborative capabilities are needed. Besides, to implement a BMR strategy, companies can adopt either/both processes, uses or innovationoriented servitization approaches, with digital productive capabilities. 
Table 3. A configurational approach to servitization. 
As represented in Table 3, when implementing their strategy manufacturing firms can adopt "either/both" of the different servitization approaches (Kohtamäki et al., 2020), but they must coherently reconsider their offering according to their resources and capabilities (digital capabilities, organisational model, etc.), and also according to roles that customers play. Customers have to be considered as a resource, but the level of their contribution will vary according to the implemented service strategy and to the type of resources they deliver towards the design and realization of the servitized value proposition.

As shown in Table 3, the customers' integration into the servitized value proposition varies according to the chosen servitization strategy determining the role customers play and the resources they provide to the supplier. Indeed, a passive customer will only participate with basic resources, such as mere information. This low level of integration may be sufficient if the manufacturing firm decides to implement an AS strategy. If proposing an AR strategy, however, customers are expected to endorse the producer. There is a higher level of expectation for them to participate and collaborate in designing the servitized value proposition. Finally, when implementing a BMR service strategy, customers have a high degree of integration in the servitized value proposition of the company: they become proactive.

Adopting a configurational approach to servitization leads to blurring the boundaries of each servitization approach (Figure 1) to fix the heterogeneity behind this concept. We propose that manufacturing firms manage their offer according to the necessary alignment of service strategies, digital capabilities and customer resources as a necessary and sufficient condition to succeed in implementing servitization. 
Figure 1. Blurring boundaries through a configurational approach to servitization 


\subsection{Multiple pathways to succeed in implementing servitization}

Manufacturing firms need to better understand the concept of servitization and its conditions of success. To help managers of manufacturing firms to come to terms with the challenges of servitization, we first proposed an innovative reading to address its heterogeneity and, through this, help them to better understand servitization and position their offers in line with their value proposition and thus with one of these different approaches.

To better support this shift from a product-centric to a service-user or service-centric model, we suggest adopting a customer-centric logic, which is common to all the approaches presented above. Moreover, to facilitate servitized value proposition design, we present a comprehensive framework that helps manufacturing firms to position their offers according to a necessary alignment of service strategies, digital capabilities and customer resources.

In line with their value propositions and the chosen servitization approaches, which correspond to their definition of servitization, companies can implement servitization in different ways and all perform as expected (Table 3 ).

Indeed, when implementing an AS service strategy, companies address a basic value proposition in which a lower degree of customer integration (passive customer) is needed, and only digital informative capabilities are needed.

In the AR service strategy, in order to address an efficient and output oriented VP, companies need more customer integration (active customer) and essentially digital collaborative capabilities are needed.

Companies that want to implement a BMR service strategy address a customer outcomesoriented VP, in which a high level of customer integration (proactive customer), and essentially productive capabilities are needed. 
These approaches suggest different levels of maturity in the servitization map of manufacturing companies (Rabetino, Kohtamäki \& Gebauer, 2017). As a consequence, multiple pathways can lead to success in servitization. Identifying the right alignment between service strategies, customer resources and digital capabilities may be challenging. However, this alignment between those concepts is required to deliver a better value proposition to their customers (Table 3) and to perform according to qualified value proposition proposals.

To conclude, we assume that there is no one best way to implement servitization, and in designing the chosen servitized value proposition companies need to consider a relevant alignment between service strategies, digital capabilities and customer resources. Our contribution provides them with a framework for determining this alignment, depending on their chosen strategy. 


\section{REFERENCES}

Ambroise, L., Prim-Allaz, I., \& Teyssier, C. (2018). Financial performance of servitized manufacturing firms: A configuration issue between servitization strategies and customer-oriented organizational design. Industrial Marketing Management, 71, 54-68. https://doi.org/10.1016/j.indmarman.2017.11.007

Baines, T. S., Lightfoot, H. W., Benedettini, O., \& Kay, J. M. (2009). The servitization of manufacturing: A review of literature and reflection on future challenges. Journal of Manufacturing Technology Management, 20(5), 547-567. https://doi.org/10.1108/17410380910960984

Baines, T. S., Ziaee Bigdeli, A., Anders, K.M., Andrews, D., Benbow, S.A., Kapoor, K., Machan, I.H. and Tumber, N. (2019). Customer value propositions for servitization: A mini-guide for manufacturers seeking to compete through advanced services. Birmingham, UK; The Advanced Services Group, Aston Business School.

Batista, L., Davis-Poynter, S., Ng, I., \& Maull, R. (2017). Servitization through outcome-based contract - A systems perspective from the defence industry. International Journal of Production Economics, 192, 133-143. https://doi.org/10.1016/j.ijpe.2016.12.005

Böhm, E., Eggert, A., \& Thiesbrummel, C. (2017). Service transition: A viable option for manufacturing companies with deteriorating financial performance? Industrial $\begin{array}{lll}\text { Marketing } \quad \text { Management, } & 60, & 101-111 .\end{array}$ https://doi.org/10.1016/j.indmarman.2016.04.007.

Bowen, B. E., Siehl, C., \& Schneider, B. (1989). A framework for analyzing customer service orientations in manufacturing. The Academy of Management Review, 14, 75-95. 
Briggs, E., Deretti, S., \& Kato, H. T. (2020). Linking organizational service orientation to retailer profitability: Insights from the service-profit chain. Journal of Business Research, 107, 271-278. https://doi.org/10.1016/j.jbusres.2018.08.038

Coreynen, W., Matthyssens, P., \& Van Bockhaven, W. (2017). Boosting servitization through digitization: Pathways and dynamic resource configurations for manufacturers. Industrial Marketing $\quad$ Management, $\quad 60, \quad 42-53$. https://doi.org/10.1016/j.indmarman.2016.04.012

Doty, D. H., Glick, W. H., \& Huber, G. P. (1993). Fit, Equifinality, and Organizational Effectiveness: A Test of Two Configurational Theories. The Academy of Management Journal, 36(6), 1196-1250. https://doi.org/10.2307/256810

Frambach, R. T., Barkema, H. G., Nooteboom, B., \& Wedel, M. (1998). Adoption of a service innovation in the business market: An empirical test of supply-side variables. Journal of Business Research, 41(2), 161-174. https://doi.org/10.1016/S0148-2963(97)000052

Gebauer, H., Fleisch, E., \& Friedli, T. (2005). Overcoming the Service Paradox in Manufacturing Companies. European Management Journal, 23(1), 14-26. https://doi.org/10.1016/j.emj.2004.12.006

Gebauer, H., Gustafsson, A., \& Witell, L. (2011). Competitive advantage through service differentiation by manufacturing companies. Journal of Business Research, 64(12), 1270-1280. https://doi.org/10.1016/j.jbusres.2011.01.015

Gobble, M. M. (2018). Digitalization, Digitization, and Innovation. Research-Technology Management, 61(4), 56-59. https://doi.org/10.1080/08956308.2018.1471280

Green, M. H., Davies, P., \& Ng, I. C. L. (2017). Two strands of servitization: A thematic analysis of traditional and customer co-created servitization and future research 
directions. International Journal of Production Economics, 192, 40-53. https://doi.org/10.1016/j.ijpe.2017.01.009

Kastalli, I. V., \& Van Looy, B. (2013). Servitization: Disentangling the impact of service business model innovation on manufacturing firm performance. Journal of Operations Management, 31(4), 169-180. https://doi.org/10.1016/j.jom.2013.02.001

Kohtamäki, M., Einola, S., \& Rabetino, R. (2020). Exploring servitization through the paradox lens: Coping practices in servitization. International Journal of Production Economics, 107619. https://doi.org/10.1016/j.ijpe.2020.107619

Kohtamäki, M., Henneberg, S. C., Martinez, V., Kimita, K., \& Gebauer, H. (2019). A Configurational Approach to Servitization: Review and Research Directions. Service Science, 11(3), 29.

Kohtamäki, M., Parida, V., Oghazi, P., Gebauer, H., \& Baines, T. (2019). Digital servitization business models in ecosystems: A theory of the firm. Journal of Business Research, 104, 380-392. https://doi.org/10.1016/j.jbusres.2019.06.027

Lenka, S., Parida, V., \& Wincent, J. (2017). Digitalization Capabilities as Enablers of Value Co-Creation in Servitizing Firms: DIGITALIZATION CAPABILITIES. Psychology \& Marketing, 34(1), 92-100. https://doi.org/10.1002/mar.20975

Malleret, V. (2006). La rentabilité des services dans les entreprises industrielles, enquête sur un postulat, communication au 26ème Congrès de l'AFC.

Martín-Peña, M.-L., Sánchez-López, J.-M., \& Díaz-Garrido, E. (2019). Servitization and digitalization in manufacturing: The influence on firm performance. Journal of Business \& Industrial Marketing, ahead-of-print(ahead-of-print). https://doi.org/10.1108/JBIM12-2018-0400 
Mathieu, V. (2001). Product services: From a service supporting the product to a service supporting the client. Journal of Business \& Industrial Marketing, 16(1), 39-61. https://doi.org/10.1108/08858620110364873

Meyer, A. D., Tsui, A. S., \& Hinings, C. R. (1993). Configurational Approaches to Organizational Analysis. Academy of Management Journal, 36(6), 1175-1195. https://doi.org/10.5465/256809

Moeller, S. (2010). Characteristics of services - a new approach uncovers their value. Journal of Services Marketing, 24(5), 359-368. https://doi.org/10.1108/08876041011060468

Neely, A. (2007). Exploring the financial consequences of the servitization of manufacturing. Operations Management Research, 1, 103-118. https://doi.org/10.1007/s12063-009$0015-5$

Neu, W. A., \& Brown, S. W. (2005). Forming Successful Business-to-Business Services in Goods-Dominant Firms. Journal of Service Research, 8(1), 3-17. https://doi.org/10.1177/1094670505276619

Oliva, R., \& Kallenberg, R. (2003). Managing the transition from products to services. International Journal of Service Industry Management, 14(2), 160-172. https://doi.org/10.1108/09564230310474138

Queiroz, S. A. B., Mendes, G. H. S., Silva, J. H. O., Ganga, G. M. D., Cauchick Miguel, P. A., \& Oliveira, M. G. (2020). Servitization and performance: Impacts on small and medium enterprises. Journal of Business \& Industrial Marketing, ahead-of-print(ahead-ofprint). https://doi.org/10.1108/JBIM-06-2019-0277

Rabetino, R., Kohtamäki, M., \& Gebauer, H. (2017). Strategy map of servitization. International Journal of Production Economics, 192, 144-156. https://doi.org/10.1016/j.ijpe.2016.11.004 
Ragin, C. C. (2008). Redesigning social inquiry: Fuzzy sets and beyond. Chicago: University of Chicago Press.

Shaltoni, A. M., West, D., Alnawas, I., \& Shatnawi, T. (2018). Electronic marketing orientation in the Small and Medium-sized Enterprises context. European Business Review, 30(3), 272-284. https://doi.org/10.1108/EBR-02-2017-0034

Sjödin, D., Parida, V., Kohtamäki, M., \& Wincent, J. (2020). An agile co-creation process for digital servitization: A micro-service innovation approach. Journal of Business Research. https://doi.org/10.1016/j.jbusres.2020.01.009

Smith, L., Maull, R., \& C.L. Ng, I. (2014). Servitization and operations management: A service dominant-logic approach. International Journal of Operations \& Production Management, 34(2), 242-269. https://doi.org/10.1108/IJOPM-02-2011-0053

Teyssier C., Ambroise L., Prim-Allaz I. \& Perez M. (2018). Digitalisation et stratégies de servicisation des PMI, CIFEPME, Toulouse, Octobre.

Valtakoski, A. (2017). Explaining servitization failure and deservitization: A knowledge-based perspective. Industrial Marketing Management, 60, 138-150. https://doi.org/10.1016/j.indmarman.2016.04.009

Vandermerwe, S., \& Rada, J. (1988). Servitization of business: Adding value by adding services. European Management Journal, 6(4), 314-324. https://doi.org/10.1016/02632373(88)90033-3

Vendrell-Herrero, F., Bustinza, O. F., Parry, G., \& Georgantzis, N. (2017). Servitization, digitization and supply chain interdependency. Industrial Marketing Management, 60, 69-81. https://doi.org/10.1016/j.indmarman.2016.06.013

Vorhies, D. W., \& Morgan, N. A. (2003). A Configuration Theory Assessment of Marketing Organization Fit with Business Strategy and Its Relationship with Marketing 
Performance. Journal of Marketing, 67(1), 100-115.

https://doi.org/10.1509/jmkg.67.1.100.18588 


\begin{tabular}{|c|c|c|}
\hline $\begin{array}{l}\text { Servitization } \\
\text { approaches }\end{array}$ & Authors & Definition \\
\hline Offer & $\begin{array}{l}\text { Vandermerwe \& Rada (1988); Vestrepen } \\
\text { \& Van Den Berg (1991); Mathieu (2001); } \\
\text { Robinson et al. (2002); Oliva \& } \\
\text { Kallenberg (2003); Ward \& Graves } \\
\text { (2005); Baines et al. (2008), (2013) }\end{array}$ & $\begin{array}{l}\text { The offer-oriented approach to servitization is considered as an extension or transformation of the offer } \\
\text { via a combination of simple services added to products. Companies tend to offer a set of products, services, } \\
\text { support, self-service and knowledge through the integration of a "products and services" duality in its } \\
\text { global offer, the aim being to take advantage of the benefits associated with services without disrupting } \\
\text { the business model. }\end{array}$ \\
\hline Processes & $\begin{array}{l}\text { Mathieu (2001); Neely (2007), (2008); } \\
\text { Baines et al. (2008), (2013); } \\
\text { Kowalkowski et al. (2017) }\end{array}$ & $\begin{array}{l}\text { The process-oriented approach to servitization is considered as a set of transformational processes through } \\
\text { which a company moves from a product-oriented to a service-oriented model, transforming the product } \\
\text { offering into a use or a result offer. Scholars propose that service-oriented businesses tend to transform } \\
\text { their processes in order to respond differently to the market, leading to new forms of services. This } \\
\text { approach foresees a shift from an industrial process to a service-based process. }\end{array}$ \\
\hline
\end{tabular}




\begin{tabular}{|c|c|c|}
\hline Uses \& & $\begin{array}{l}\text { Oliva \& Kallenberg (2003); Baines et al. } \\
\text { (2008), (2013); Oliva \& Kallenberg } \\
\text { (2003); Lewis et al. (2004); Baines et al. } \\
\text { (2008), (2013) }\end{array}$ & $\begin{array}{l}\text { The use and result-oriented approach to servitization is considered as a strategy that changes the way in } \\
\text { which functionalities are delivered to their markets. This refers to the service typology (basic, intermediate } \\
\text { and advanced services) of Baines et al. (2009). The use and results-oriented servitization approach } \\
\text { recommends the creation of services with new functionalities that are measurable and might provide } \\
\text { greater added value, resulting in a performance contract proposal, through selling use or result. This may } \\
\text { lead to business model disruption. }\end{array}$ \\
\hline Innovation & $\begin{array}{l}\text { Tellus Institute (1999); Desmet et al. } \\
\text { (2003); Neely (2007), (2008); Baines et } \\
\text { al. (2008), (2013); Parida et al. (2015); } \\
\text { Huikkola \& Kohtamäki (2017); Sjödina } \\
\text { et al. (2020) }\end{array}$ & $\begin{array}{l}\text { The innovation-oriented approach to servitization is a way to innovate through services and improve the } \\
\text { core activity of manufacturing firms: manufacturing firms are increasingly integrating services into their } \\
\text { offerings in order to pursue innovation objectives. The innovation-oriented approach looks at servitization } \\
\text { through two approaches: innovating through the process and innovating for, and with, the customer. }\end{array}$ \\
\hline
\end{tabular}

Table 1. The necessary re-examination of the current understanding of servitization: different servitization approaches 
The AS strategy (-do it themselves-) does not fundamentally change the customer's value chain but allows the supplier to extend its offer and expand opportunities. Ownership is transferred from the supplier to the customer, along with the associated risks. This corresponds to the first level of VP, the basic one, where manufacturing companies propose products and product spares to the customer (Baines et al., 2019), training materials, documentation, breakdown services, consumables and maintenance tools (Teyssier et al., 2018).

The AR strategy (-do it with them-) helps manufacturing companies to become providers of products and services by integrating customers into their business model and value chain: this allows them to co-develop offers and/or processes with the customer and to outsource services. We name this second level of VP “output-oriented": it integrates product break/fix, assured maintenance and performance advice, predictive maintenance and monitoring to improve customers' use of equipment, outsourcing, co-design or co-production activities (Baines et al., 2019; Teyssier et al., 2018; Gebauer et al., 2010).

BMR strategy (-do it for them-) involves a change in the business model of the supplier and the customer as well as in their relationship model. It refers to the industrial supplier accepting a use or result-oriented arrangement with its customer, which will change not only their offerings but also their mutual organisational processes and their revenue and profit equations. Therefore, this strategy has significant strategic, organisational and financial implications for both the provider and the customer (Ambroise et al., 2018). Suppliers have to integrate customers more in terms of asset, process and platform (Baines et al., 2019), and they provide an integrated product-service solution that guarantees different customers' outcomes. We name this VP "the customer outcomes oriented" VP.

Table 2. Service strategies and servitized value propositions (Ambroise et al., 2018; Baines et al., 2019) 


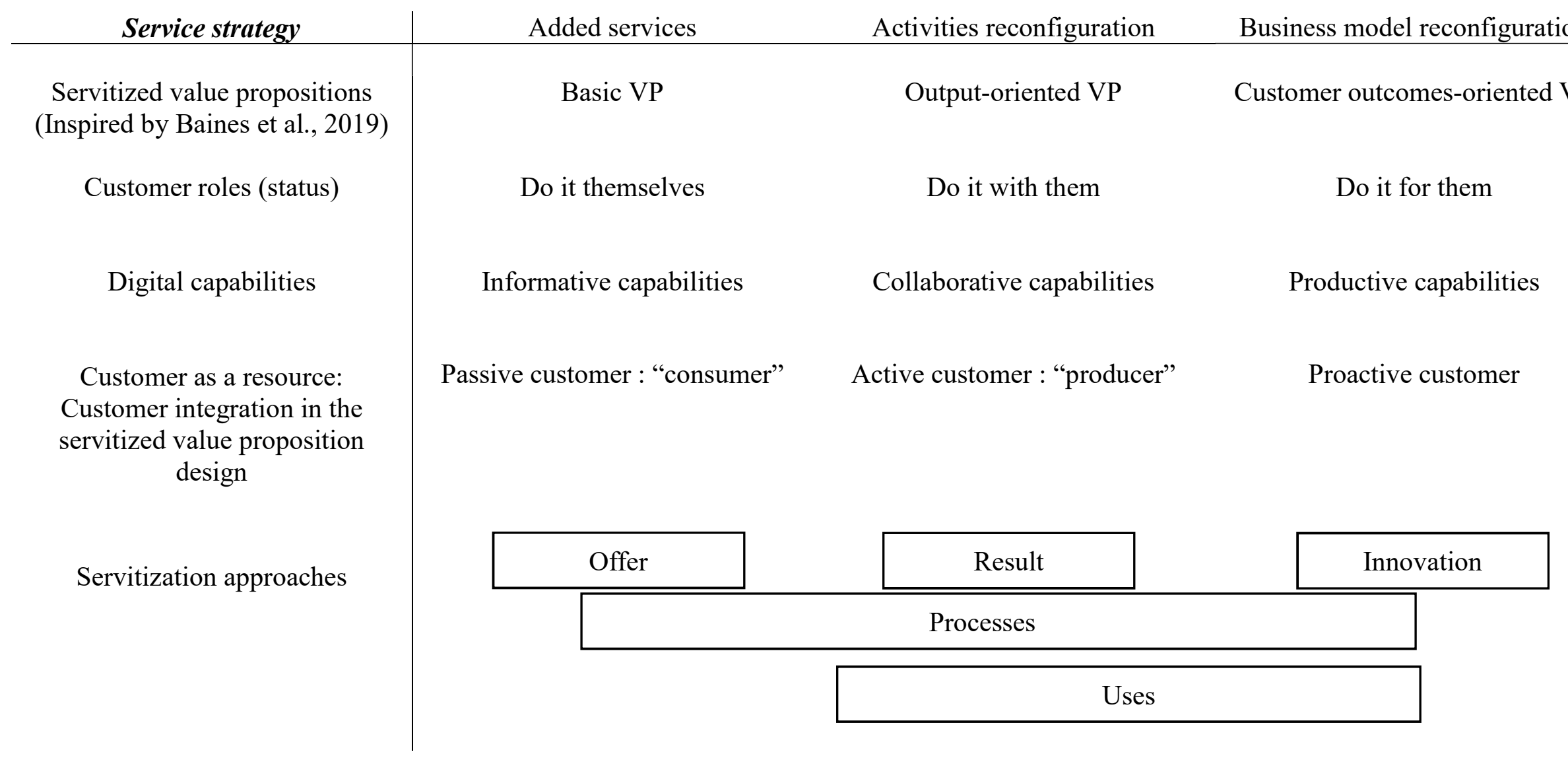

Table 3. A configurational approach to servitization 


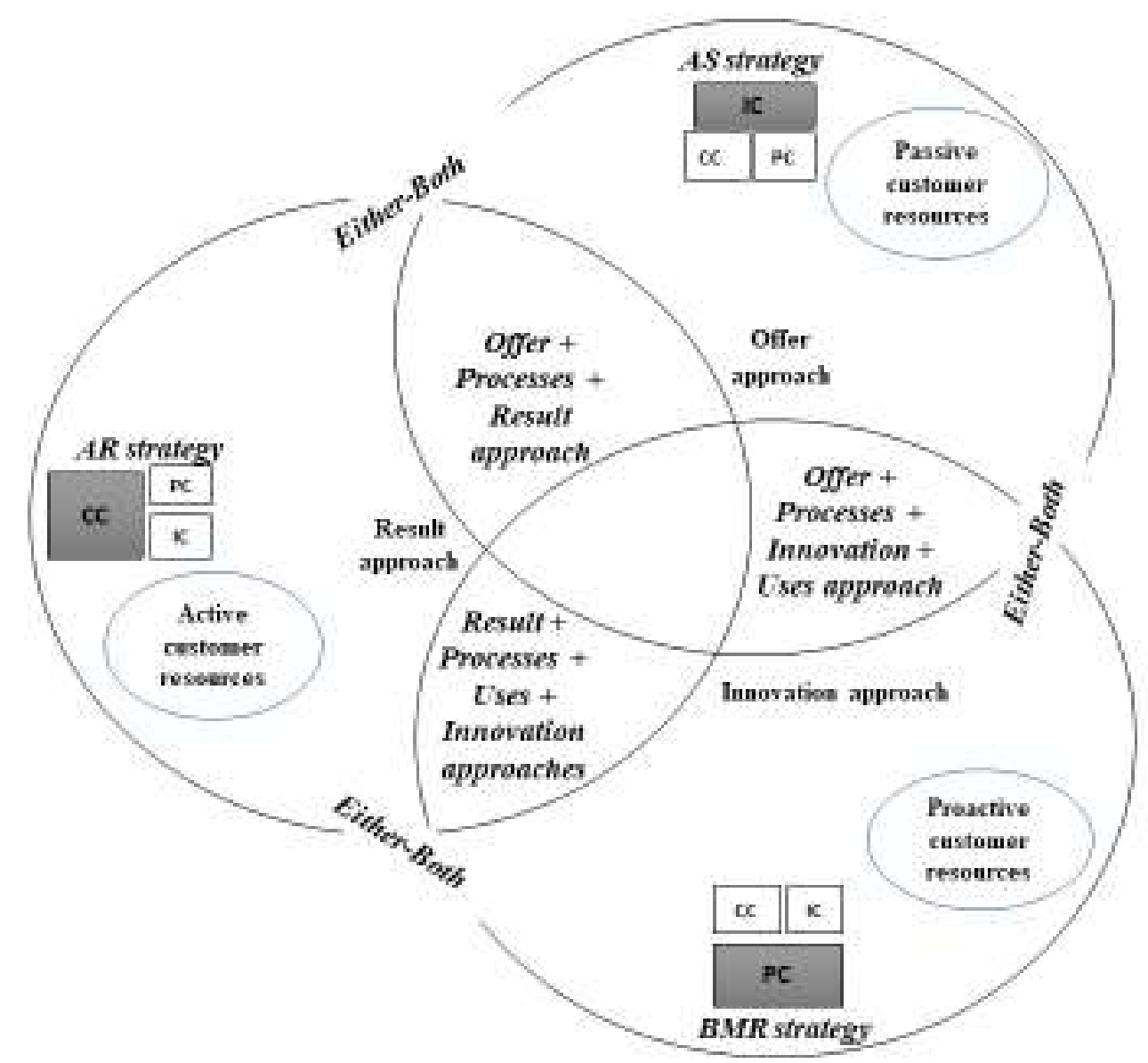

Figure 1. Bluring boundries through a conflgurational approach to sentization 